\title{
ROLE OF PHYSICAL ENVIRONMENT TO ORIENTATION AND MOBILITY OF BLIND IN PSBN WYATA GUNA BANDUNG
}

\author{
${ }^{1}$ Elva. ${ }^{2}$ Dr. Ir. Hartanto Budiyuwono, M.T. \\ ${ }^{1}$ Student in the Bachelor's (S-1) Study Program in Architecture \\ at Parahyangan Catholic University \\ ${ }^{2}$ Senior lecturer in the Bachelor's (S-1) Study Program in Architecture \\ at Parahyangan Catholic University
}

\begin{abstract}
Visually impaired is a general term to describe the condition of a person experiencing disability to their sense of sight. Due to the disability, the process of orientation and mobility of the people with visually impairment is inhibited. Therefore they try to increase their sensitivity of other senses like sense of touch, sense of smell, and sense of hearing to obtain information from the surrounding physical environment. PSBN Wyata Guna is a residential for the visually impaired, as the physical environment it must have physical elements that can provide information which affect effectivelly to the orientation and mobility of the visually impaired. The purpose of this study is to find out what physical elements in the environment of PSBN Wyata Guna that affect the orientation and mobility of the visually impaired and how effective the influence of these elements.

This study use qualitative descriptive methods by mapping the behavior of fourteen respondents (personcentered mapping) who do orientation and mobility in the physical environment of PSBN Wyata Guna. Physical environments are classified based on elements that define the space, ie horizontal and vertical planes, which is, tactile pavements, materials differences, Ramps, steps, corridor columns, ceramic walls, shrubs, and hand railling. Observations held on Saturday and Sunday in the morning-afternoon when most of visually impaired do their activities outside the dorm.

The result of this research shows that people with visual impairment in the environment of PSBN Wyata Guna use the physical environment to obtain information for their orientation and mobility. This orientation and mobility activity is mostly affected by tactile pavements, ceramic walls, and Ramps. Shrubs and hand railling have less role to the orientation and mobility of the visually impaired. Thus, it can be concluded that the physical environment of PSBN Wyata Guna is influential in the orientation and mobility of the visually impaired.
\end{abstract}

Key Words: orientation and mobility, visually impaired, physical environments, physical elements, PSBN Wyata Guna

\section{PERANAN LINGKUNGAN FISIK TERHADAP ORIENTASI DAN MOBILITAS PENYANDANG TUNANETRA DI PSBN WYATA GUNA BANDUNG}

\author{
${ }^{1}$ Elva. ${ }^{2}$ Dr. Ir. Hartanto Budiyuwono, M.T. \\ ${ }^{1}$ Mahasiswa S1 Program Studi Arsitektur Universitas Katolik Parahyangan. \\ 2 Dosen Pembimbing S1 Program Studi Arsitektur Universitas Katolik Parahyangan
}

\begin{abstract}
Abstrak- Tunanetra merupakan istilah umum yang digunakan untuk menggambarkan kondisi seseorang yang mengalami hambatan atau gangguan pada indra penglihatannya. Akibat hambatan atau gangguan pada fungsi indra penglihatan, maka proses orientasi dan mobilitas penyandang tunanetra seringkali terhambat. Karenanya mereka berusaha memaksimalkan indra-indra lainnya yang masih berfungsi seperti perabaan, penciuman, dan pendengaran untuk memperoleh konsep informasi dari lingkungan fisik sekitarnya. PSBN Wyata Guna sebagai lingkungan fisik tempat tinggal bagi penyandang tunanetra tentunya memiliki elemen-elemen fisik yang dapat memberikan konsep
\end{abstract}

\footnotetext{
${ }^{1}$ Corresponding Author: elva_tee@hotmail.com
} 
informasi yang efektif berperan dalam orientasi dan mobilitas penyandang tunanetra. Tujuan dari penelitian ini adalah mengetahui elemen fisik apa saja di lingkungan PSBN Wyata Guna yang berperan dalam orientasi dan mobilitas penyandang tunanetra dan sejauh mana efektivitas dari keberadaan elemen-elemen fisik tersebut.

Metode yang digunakan pada penelitian ini adalah deskriptif kualitatif dengan melakukan pemetaan perilaku secara person-centered mapping dari empat belas orang responden yang melakukan orientasi dan mobilitas di lingkungan fisik PSBN Wyata Guna. Lingkungan fisik dikelompokkan berdasarkan hasil pengamatan mengenai elemen-elemen yang mendefinisikan ruang, yaitu bidang horizontal dan bidang vertikal, antara lain, ubin pemandu, beda material, tanjakan, undakan, turunan, tiang koridor, dinding keramik, tanaman perdu, dan hand railling. Pengamatan dilakukan di hari Sabtu dan Minggu pada waktu pagi hingga siang hari ketika penyandang tunanetra sering beraktivitas di luar asrama.

Berdasarkan hasil penelitian, penyandang tunanetra di lingkungan PSBN Wyata Guna memanfaatkan lingkungan fisik sebagai konsep informasi untuk mereka melakukan orientasi dan mobilitas. Aktivitas orientasi dan mobilitas ini terutama dipengaruhi oleh ubin pemandu, dinding keramik, dan tanjakan-turunan. Tanaman perdu dan hand railling kurang berperan terhadap orientasi dan mobilitas penyandang tunanetra. Jadi, dapat disimpulkan bahwa lingkungan fisik PSBN Wyata Guna berperan dalam orientasi dan mobilitas penyandang tunanetra.

Kata Kunci: orientasi dan mobilitas, tunanetra, lingkungan fisik, elemen fisik, PSBN Wyata Guna

\section{PENDAHULUAN}

Pengertian tunanetra merujuk pada seseorang yang mengalami gangguan atau hambatan pada indra penglihatannya. Di Indonesia, penyandang tunanetra selama ini masih menjadi bagian dari masyarakat yang termajinalkan. Oleh karena itu, untuk meningkatkan kualitas hidup mereka, pemerintah mendirikan Panti Sosial Bina Netra (PSBN) yang tersebar di seluruh pelosok wilayah di Indonesia, salah satunya adalah PSBN Wyata Guna di Kota Bandung, Jawa Barat.

Sebagai tempat tinggal sementara, PSBN Wyata Guna mewadahi berbagai aktivitas penyandang tunanetra yang tinggal di dalamnya. Untuk mewadahi aktivitas-aktivitas tersebut PSBN Wyata Guna dilengkapi sarana dan prasarana seperti kompleks hunian pada umumnya. Tidak terkecuali prasarana jalur sirkulasi yang mewadahi aktivitas orientasi dan mobilitas penyandang tunanetra.

PSBN Wyata Guna sebagai wujud arsitektur yang membentuk lingkungan fisik sekitar, berperan penting dalam memberikan konsep informasi yang dapat ditangkap oleh indra-indra lain penyandang tunanetra yang masih berfungsi untuk memudahkan mereka melakukan orientasi dan mobilitas.

Orientasi adalah proses penggunaan indra-indra yang masih berfungsi untuk menetapkan posisi diri dan kaitannya dengan objek-objek yang ada dalam lingkungan sekitarnya. Kesiapan mental sangat diperlukan sebagai dasar dari kemampuan orientasi. Mobilitas adalah kemampuan, kesiapan, dan kemudahan untuk bergerak dan berpindah tempat dalam suatu lingkungan. Karena mobilitas terkait erat dengan gerak dan perpindahan fisik, maka kesiapan fisik akan sangat menentukan keteRampilan penyandang tunanetra dalam mobilitas.

Jadi menurut pengertian tersebut di atas secara prinsip orientasi dan mobilitas adalah kemampuan bergerak dari satu tempat ke tempat lain dengan memaksimalkan penggunaan semua indra yang masih ada untuk menentukan posisi seseorang terhadap benda-benda penting yang ada di lingkungan sekitarnya, baik secara temporal maupun spasial. Orientasi tidak akan berguna tanpa mobilitas dan sebaliknya mobilitas tidak akan berhasil dan efektif tanpa memiliki dasar orientasi.

Ada lima tahapan dalam proses orientasi dan mobilitas, yaitu persepsi, analisis, seleksi, perencanaan, dan eksekusi. Kunci dari kemampuan orientasi dan mobilitas seorang manusia adalah kesadaran ruang/ lingkungan sekitar dan bagi penyandang tunanetra yang mengalami gangguan 
pada indra penglihatannya (terutama sejak lahir), lebih sulit untuk mengembangkan persepsi tentang lingkungan sekitarnya.

\section{KAJIAN TEORI}

Menurut Jose Bernardo "Konsep suara, bau, dan rasa yang membentuk lingkungan sangat tidak berarti bagi orang berpenglihatan normal tetapi bagi penyandang tunanetra hal ini justru sangat berarti. Orang berpenglihatan normal akan meremehkan Ramp yang mengarah ke suatu ruang, perbedaan material lantai dari yang lunak ke perkerasan, perubahan dinding ruang yang keras menjadi dinding dengan penutup yang lunak, mereka meremehkannya karena hal-hal itu dianggap sebagai detail/ bagian kecil. Berbeda dengan penyandang tunanetra. Bagi penyandang tunanetra hal-hal detail tersebut adalah petunjuk bagi mereka. Petunjuk-petunjuk inilah yang mendefinisikan ruang mereka dan menjadi satu-satunya cara penyandang tunanetra untuk memiliki gambaran akan ruang sekitar mereka."

Menurut Modul Pembimbingan Orientasi Mobilitas, penyandang tunanetra dapat lebih memahami lingkungan fisiknya, setidaknya melalui lima komponen khusus orientasi, yaitu ciri medan (landmarks), petunjuk (clues), penomoran (numbering system), pengukuran (measurement), dan compass direction. Kelima hal ini memiliki satu tujuan yaitu untuk memberikan rangsangan dan informasi yang membantu memudahkan penyandang tunanetra mencapai tujuan yang diinginkannya dalam proses orientasi dan mobilitas. Dengan adanya pemahaman tentang ciri medan (landmarks), petunjuk (clues), penomoran (numbering system), pengukuran (measurement), dan compass direction, maka penyandang tunanetra dapat lebih mudah menentukan posisi dalam lingkungan dan arah orientasi, memiliki titik orientasi (point of reference), menentukan objek yang akan dituju, dan memiliki "bantuan" untuk menentukan langakah selanjutnya.

Untuk menciptakan suatu tempat tinggal sementara yang nyaman bagi penyandang tunanetra, maka diperlukan perencanaan lingkungan fisik yang tepat. Diharapkan dengan penelitian ini ditemukan elemen lingkungan fisik yang berperan secara efektif sehingga dapat dijadikan pertimbangan dan masukan dalam mendesain lingkungan fisik yang memberikan kemudahan dan kenyamanan bagi penyadang tunanetra untuk beraktivitas ke depannya.

Penelitian mengenai lingkungan fisik pada PSBN Wyata Guna dilakukan untuk mengetahui apakah elemen-elemen dari lingkungan fisik PSBN Wyata Guna berperan dalam orientasi dan mobilitas penyandang tunanetra.

\section{METODA PENELITIAN}

Metode yang digunakan pada penelitian ini adalah metode deskriptif kuantitatif dengan melakukan pemetaan perilaku secara person-centered mapping dari empat belas orang responden yang melakukan orientasi dan mobilitas di lingkungan fisik PSBN Wyata Guna. Data-data diperoleh dari: (1) Studi literatur dengan mempelajari mengenai tunanetra, orientasi dan mobilitas, teknik orientasi dan mobilitas serta elemen fisik pembentuk ruang. (2) Pengamatan langsung ke PSBN Wyata Guna. (3) Melakukan wawancara dan mengadakan pengamatan perilaku penyandang tunanetra (14 responden).

\section{ANALISA}




\subsection{DATA LINGKUNGAN FISIK DI PSBN WYATA GUNA}

Dalam proses orientasi dan mobilitas, ada dua hal dari lingkungan fisik yang berperan dalam memberikan konsep informasi bagi penyandang tunanetra. Hal pertama, terkait kegiatan orientasi, maka penyandang tunanetra harus mengetahui dimana dia dan kemana tujuannya. Ini berhubungan dengan bangunan sebagai lingkungan fisik. Hal kedua, terkait kegiatan mobilitas, maka penyandang tunanetra harus mampu mencapai tempat tujuannya. Ini berhubungan dengan prasarana jalur sirkulasi di lingkungan PSBN Wyata Guna.

\section{Bangunan}

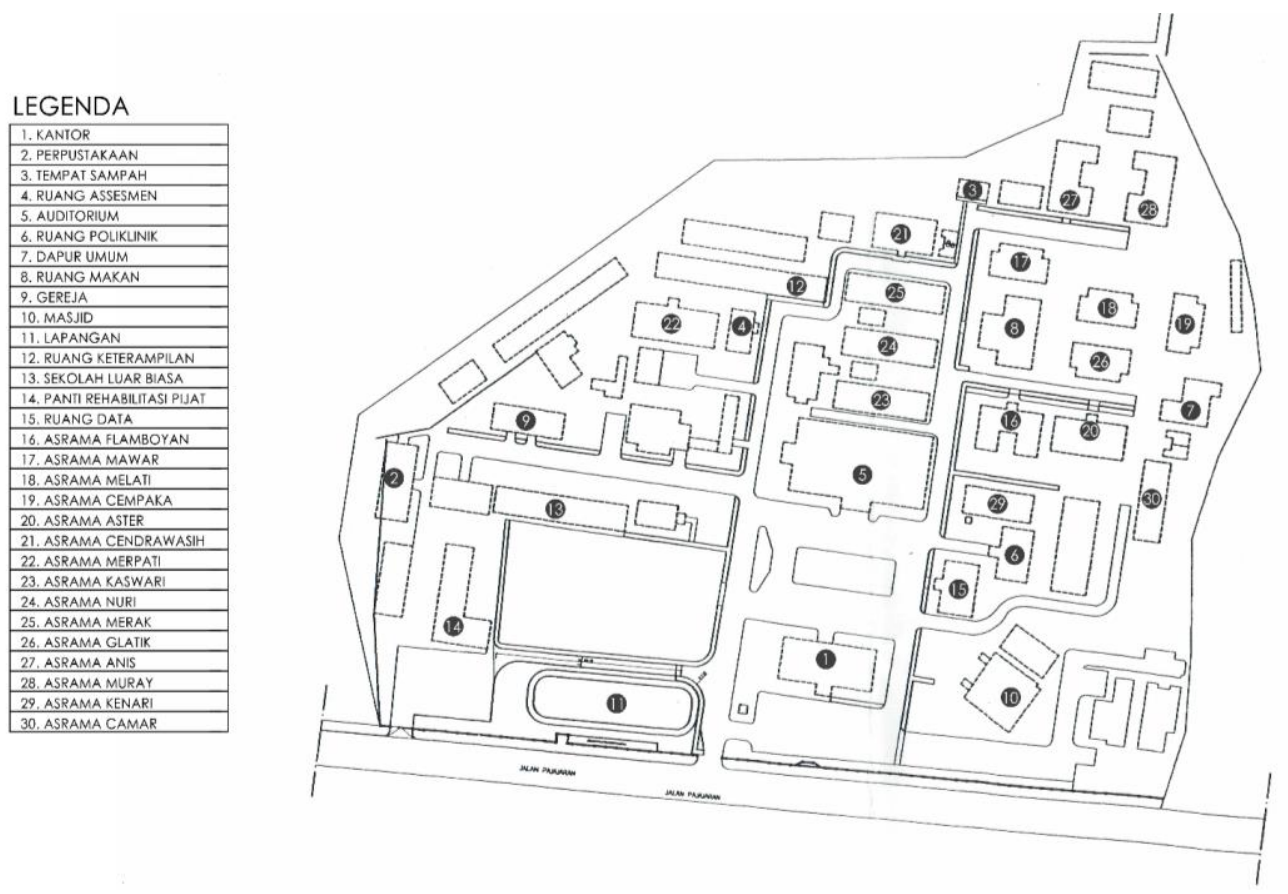

Figur 1. Rencana Tapak PSBN Wyata Guna

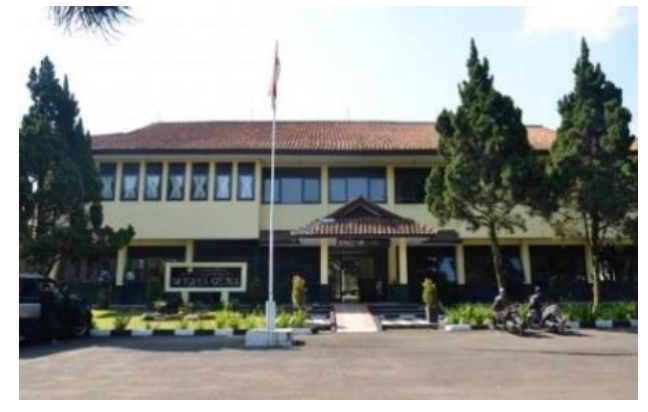

Figur 2. Kantor

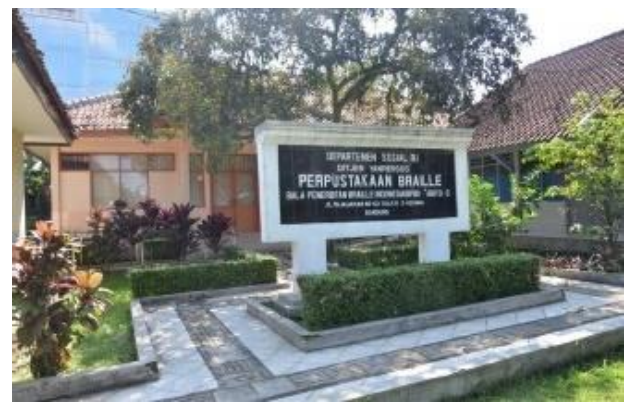

Figur 3. Perpustakaan 


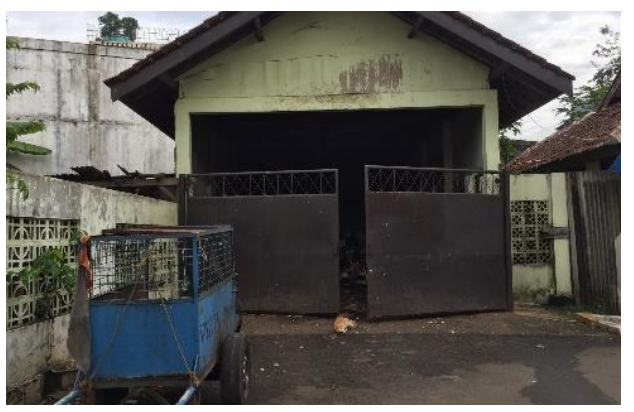

Figur 4. Tempat Sampah

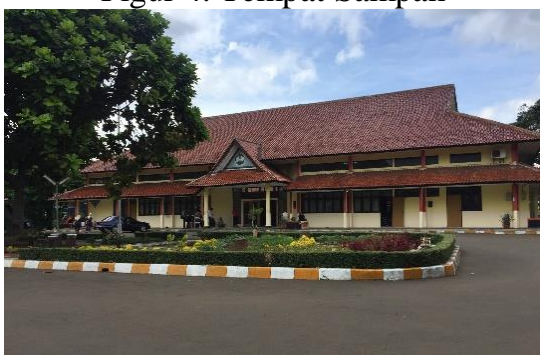

Figur 6. Auditorium

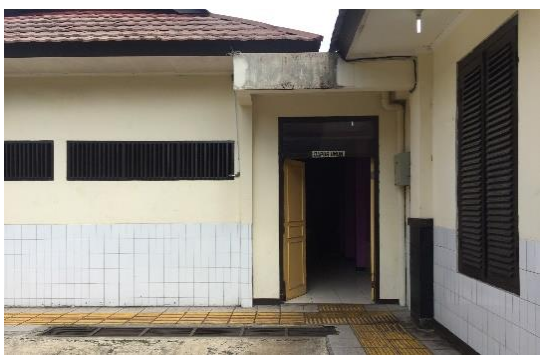

Figur 8. Dapur Umum

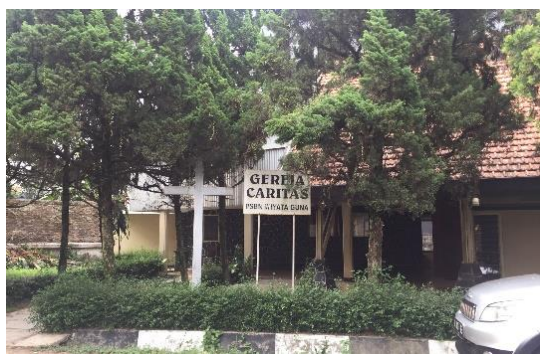

Figur 10. Gereja

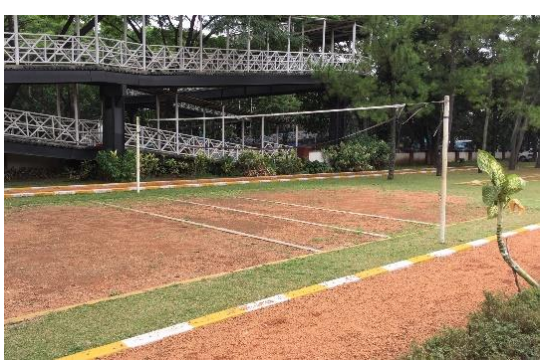

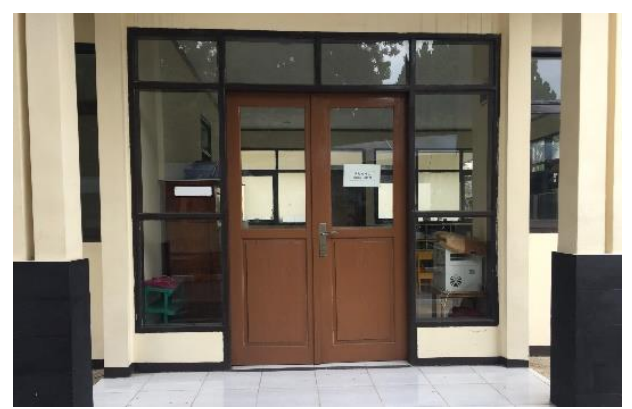

Figur 5. Ruang Assesmen

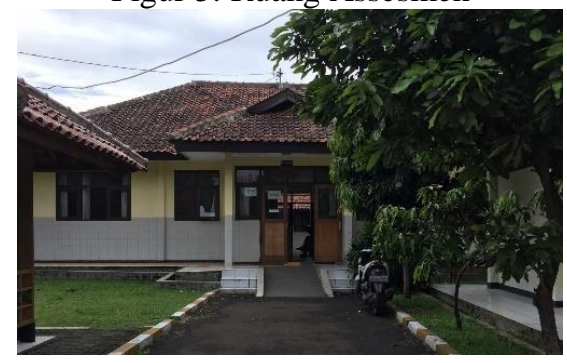

Figur 7. Ruang Poliklinik

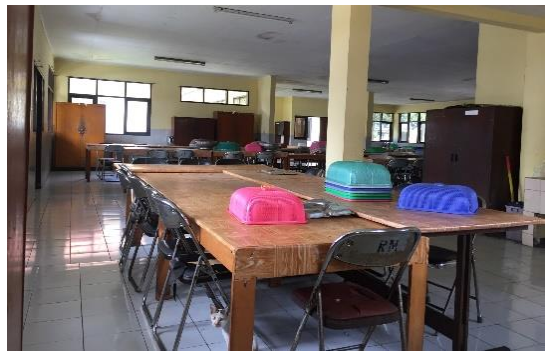

Figur 9. Ruang Makan

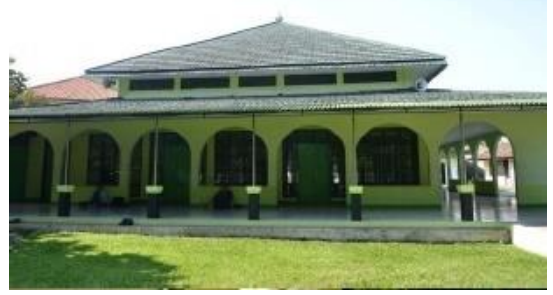

Figur 11. Masjid

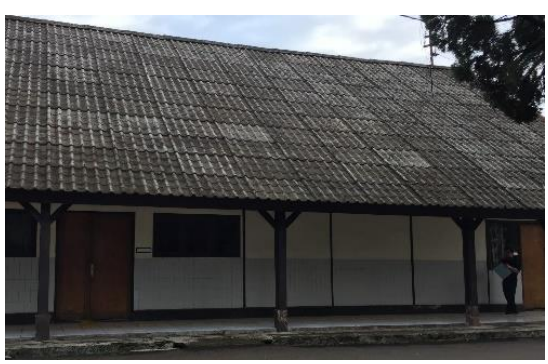


Figur 12. Lapangan

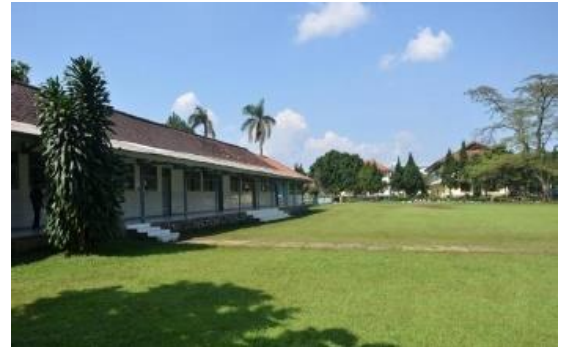

Figur 14. Sekolah Luar Biasa

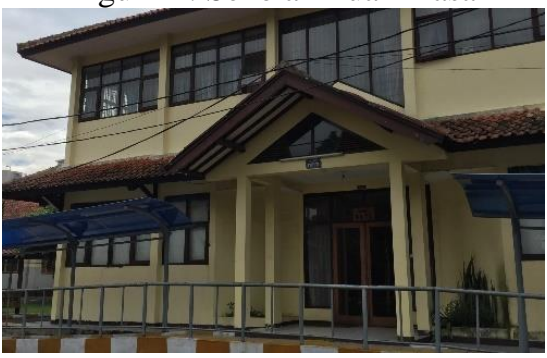

Figur 16. Ruang Data

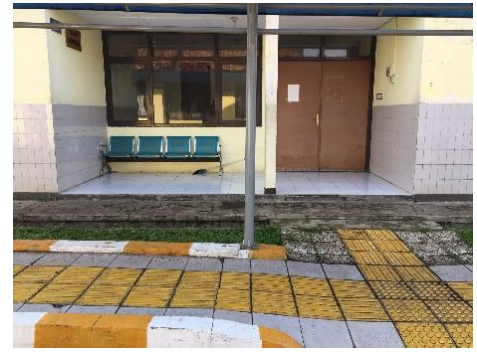

Figur 18. Asrama Mawar

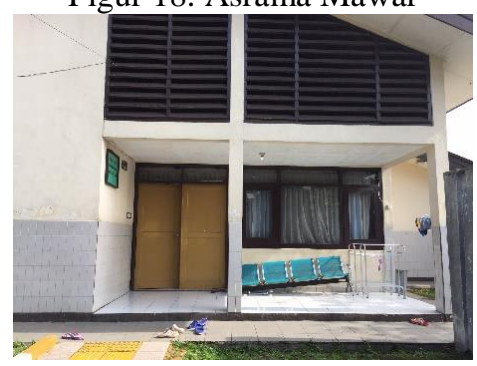

Figur 20. Asrama Cempaka
Figur 13. Ruang KeteRampilan

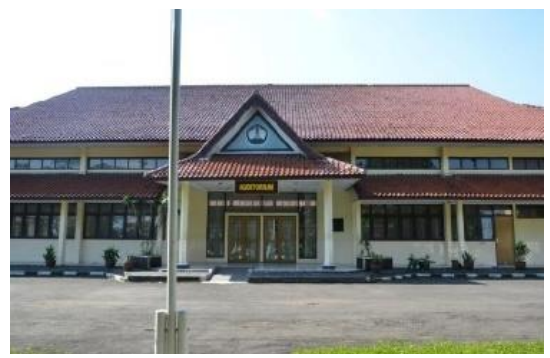

Figur 15. Panti Rehabilitasi (pijat shiatsu)

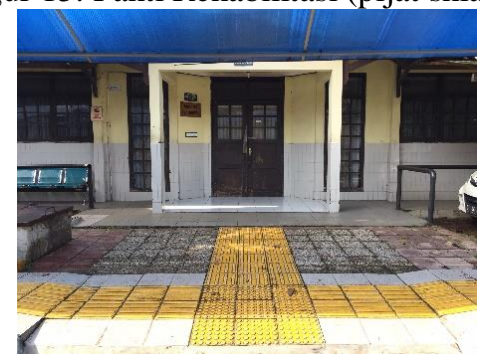

Figur 17. Asrama Flamboyan

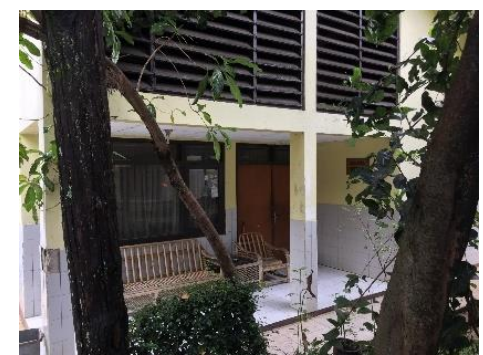

Figur 19. Asrama Melati

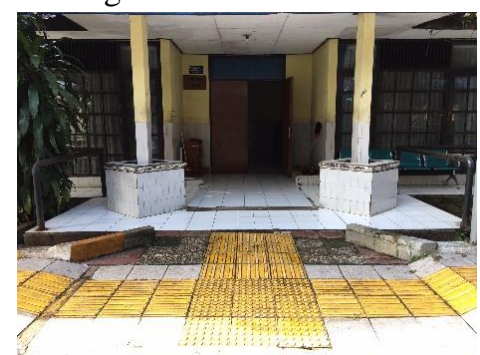

Figur 21. Asrama Aster 


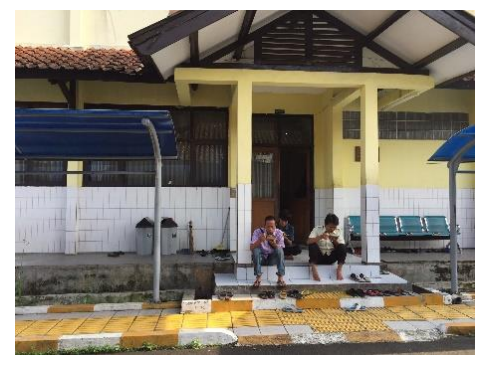

Figur 22. Asrama Cendrawasih

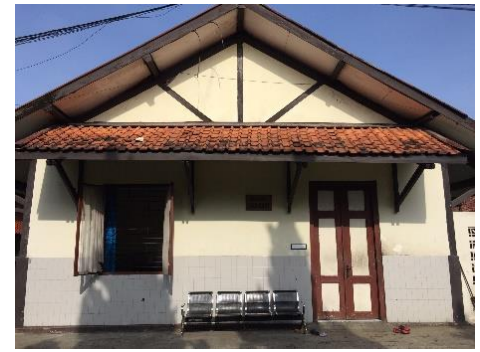

Figur 24. Asrama Kaswari

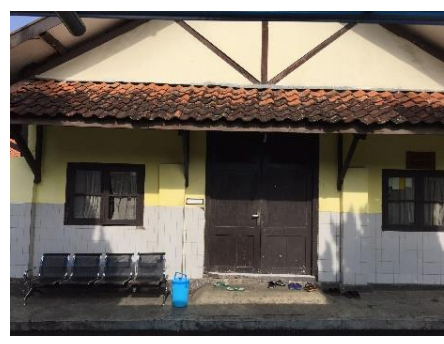

Figur 26. Asrama Merak

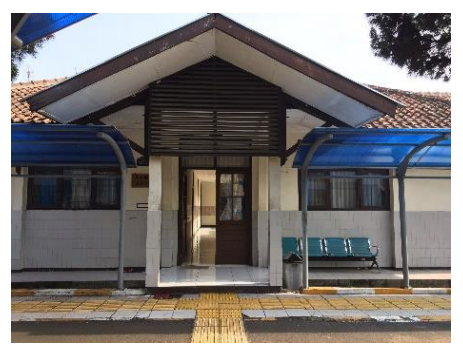

Figur 28. Asrama Anis

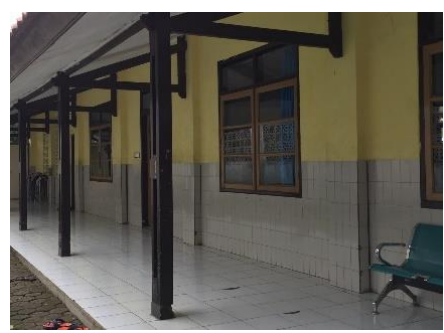

Figur 30. Asrama Kenari

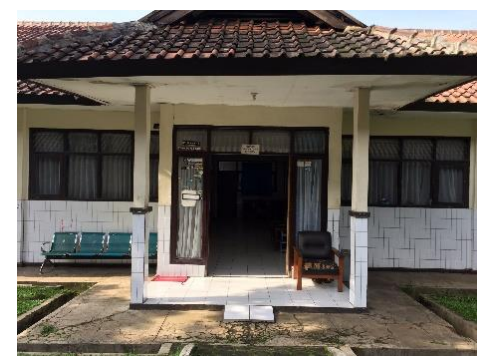

Figur 23. Asrama Merpati

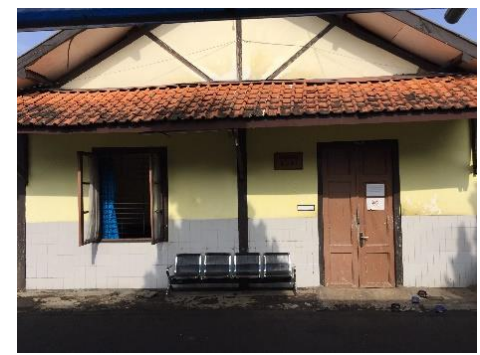

Figur 25. Asrama Nuri

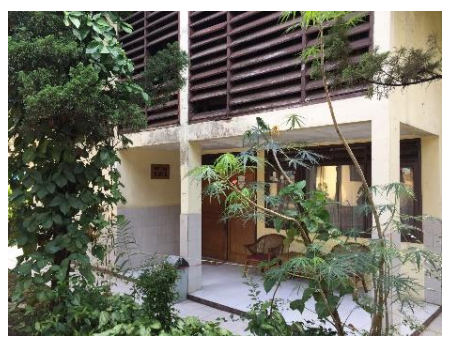

Figur 27. Asrama Glatik

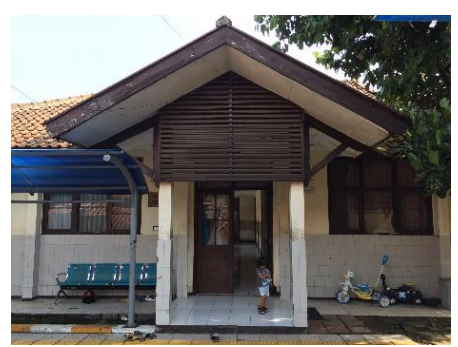

Figur 29. Asrama Muray

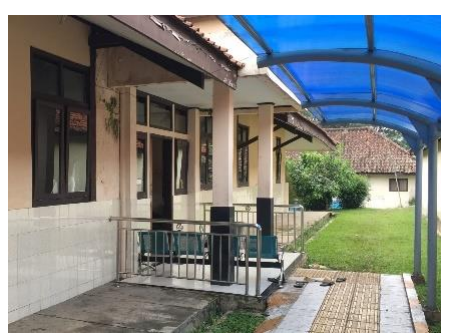

Figur 31. Asrama Camar 


\section{Jalur Sirkulasi Pedestrian 1}

Jalur sirkulasi ini merupakan jalur utama yang menghubungkan pintu masuk PSBN Wyata Guna hingga ke asrama-asrama penyandang tunanetra di sisi Utara. Jalur ini tersusun oleh keramik 30 x $30 \mathrm{~cm}$ yang dilengkapi dengan ubin pemandu serta terlindung oleh naungan sederhana dengan atap berbahan fiber berwarna biru setinggi 2.5 meter. Lebar jalur ini adalah 1.2 meter dengan curb yang dinaikkan $10 \mathrm{~cm}$ di satu sisi dan curb yang diturunkan $18 \mathrm{~cm}$ di sisi yang lainnya sebagai pembatas jalur. Kemudian terdapat jalan aspal selebar 3.5 meter untuk jalur kendaraan bermotor yang dibatasi oleh curb setinggi $18 \mathrm{~cm}$ sebelum masuk ke area rumput dan saluran drainase.

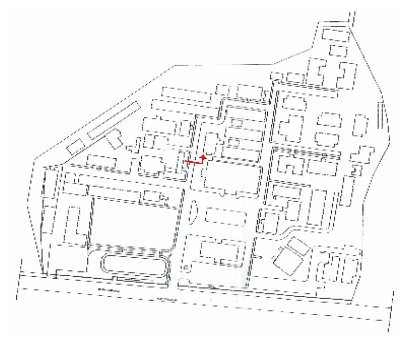

Figur 32. Letak Jalur Sirkulasi 1 di Rencana Tapak PSBN Wyata Guna

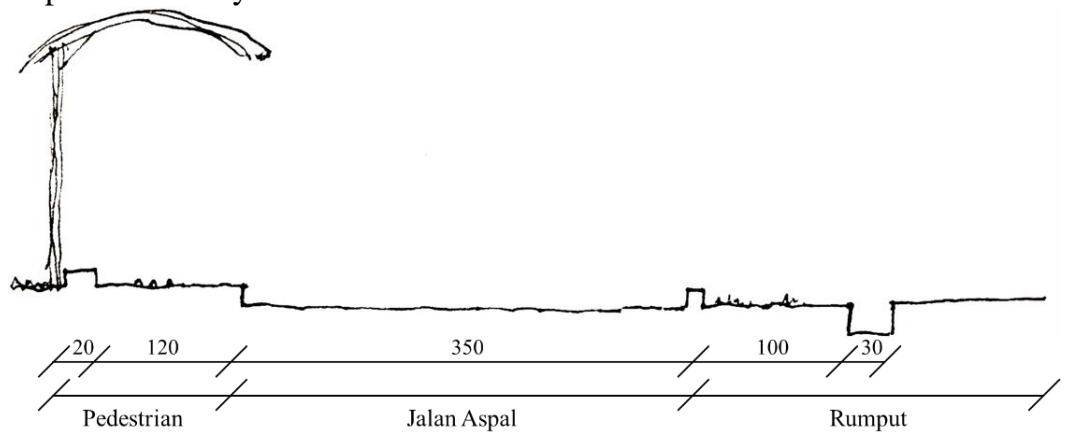

Figur 34. Potongan Jalur Sirkulasi 1

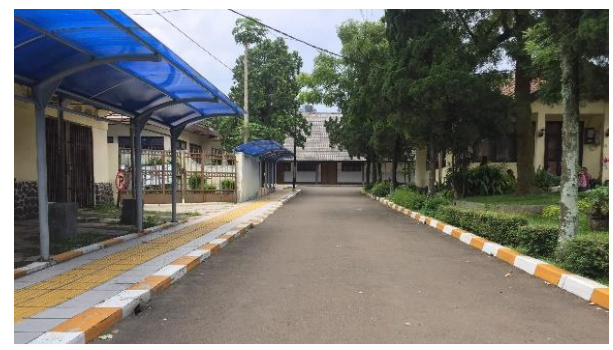

Figur 33. Jalur Sirkulasi 1

\section{Jalur Sirkulasi Pedestrian 2}

Jalur ini berada di sisi Barat PSBN Wyata Guna menuju ke Panti Pijat Shiatsu. Meskipun merupakan salah satu jalur utama, namun jalur ini belum dilengkapi oleh ubin pemandu pada jalur sirkulasinya. Lebar jalur sirkulasi pun tergolong sempit hanya $60 \mathrm{~cm}$ pada kedua sisi jalan aspal selebar 3 meter, yang letaknya lebih rendah $20 \mathrm{~cm}$ dari jalur pedestrian. Satu jalur pedestrian berbatasan dengan lapangan tanah merah sedang satu jalur yang lainnya berbatasan dengan bidang rumput sebagai halaman dari sekolah luar biasa. 


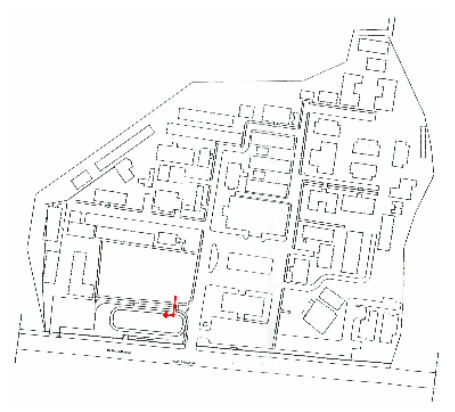

Figur 35. Letak Jalur Sirkulasi 2 di Rencana Tapak PSBN Wyata Guna

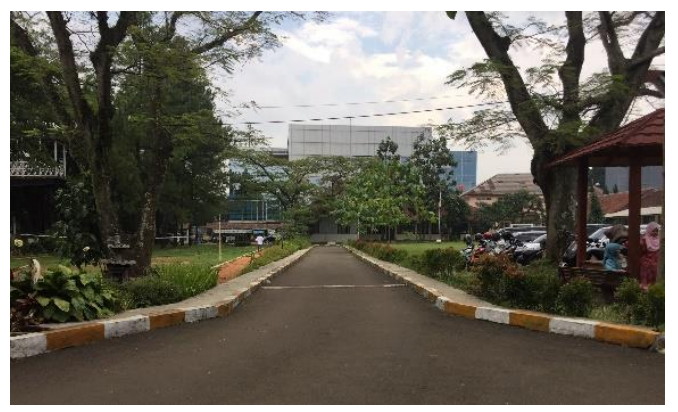

Figur 36. Jalur Sirkulasi 2

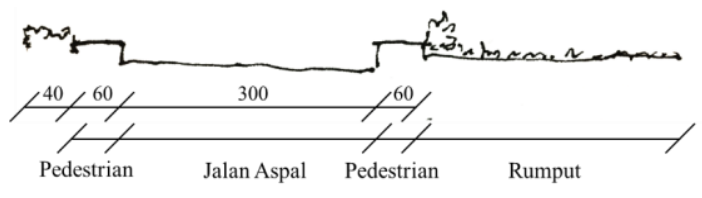

Figur 37. Potongan Jalur Sirkulasi 2

\section{Jalur Sirkulasi Pedestrian 3}

Jalur sirkulasi ini merupakan jalur sekunder yang menghubungkan jalan utama dengan fungsi-fungsi penunjang, seperti gereja, rumah dinas, sekolah luar biasa, perpustakaan, dll. Jalur ini tersusun dari paving block yang dilengkapi ubin pemandu namun tidak memiliki naungan seperti jalur lainnya. Terdapat tanaman perdu setinggi 1.2 meter sebagai pembatas di salah satu sisinya, sedangkan di sisi lain terdapat Ramp menurun ke jalan aspal. Perbedaan ketinggian antara jalur pedestrian dan jalan aspal sekitar $10 \mathrm{~cm}$. Pembatas antara jalan aspal dengan rumput dan saluran drainase adalah curb setinggi $15 \mathrm{~cm}$.

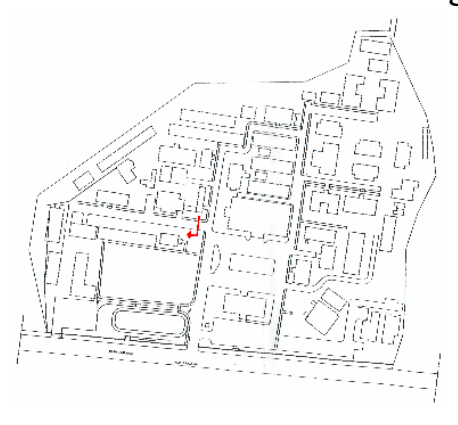

Figur 38. Letak Jalur Sirkulasi 3 di Rencana Tapak PSBN Wyata Guna

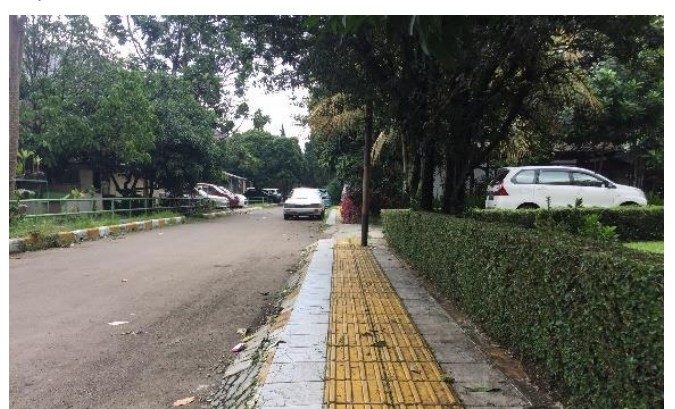

Figur 39. Jalur Sirkulasi 3

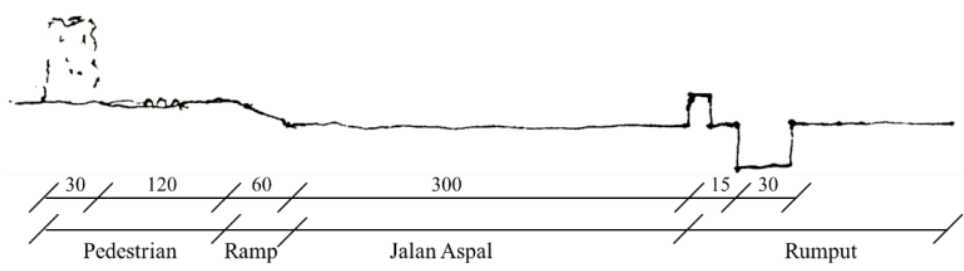

Figur 40. Potongan Jalur Sirkulasi 3 


\section{Jalur Sirkulasi Pedestrian 4}

Jalur ini berada di koridor kelas keteRampilan sehingga ternaungi oleh atap bangunan kelas. Jalur ini menggunakan keramik 30 x $30 \mathrm{~cm}$ sebagai penutup lantai serta dilengkapi ubin pemandu. Terdapat dinding kelas berwarna putih yang dilapis keramik setinggi 1.2 meter di salah satu sisi jalur pedestrian. Di sisi lain terdapat perbedaan elevasi yang diturunkan setinggi $5 \mathrm{~cm}$ yang berbatasan dengan saluran drainase selebar $30 \mathrm{~cm}$. Saluran drainase berbatasan langsung dengan jalan aspal selebar 3.5 meter.

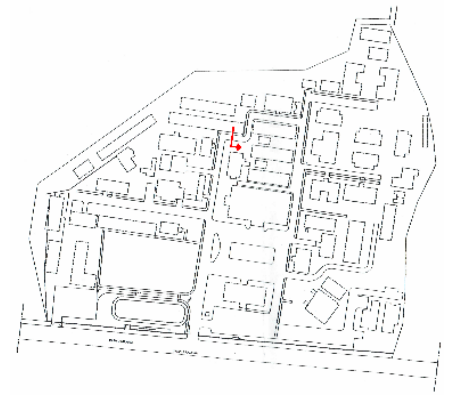

Figur 41. Letak Jalur Sirkulasi 4 di Rencana Tapak PSBN Wyata Guna

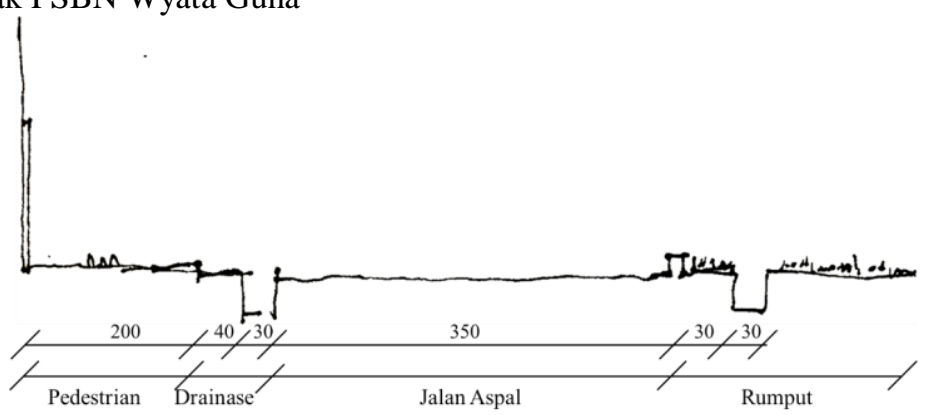

Figur 43. Potongan Jalur Sirkulasi 4

\section{Jalur Sirkulasi Pedestrian 5}

Jalur ini berada di depan asrama cendrawasih yang berhadapan dengan asrama Merak. Seperti jalur lainnya di PSBN Wyata Guna, jalur ini menggunakan keramik 30 x $30 \mathrm{~cm}$ sebagai penutup lantai serta dilengkapi ubin pemandu. Dinaungi dengan atap sederhana setinggi 2.5 meter, berbahan fiber warna biru, memberikan teduhan sehingga penyandang tunanetra yang melewatinya merasa nyaman. Terdapat perbedaan elevasi (curb) di kedua sisinya setinggi $10 \mathrm{~cm}$ yang membatasi dengan jelas jalur pedestrian. 


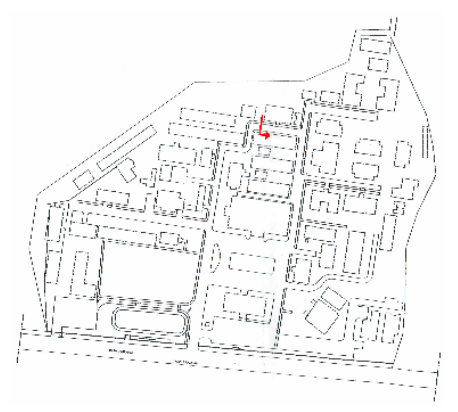

Figur 44. Letak Jalur Sirkulasi 5 di Rencana Tapak PSBN Wyata Guna

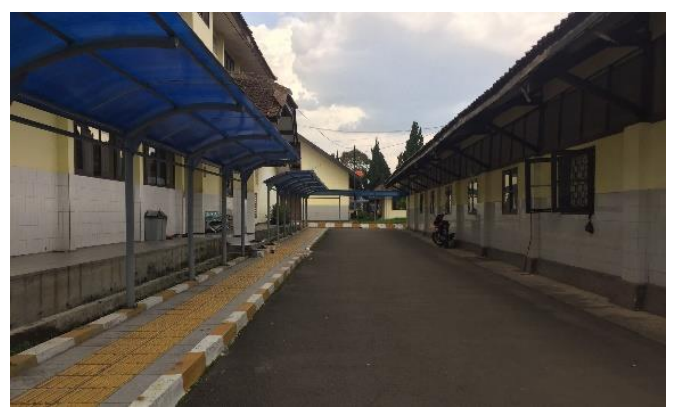

Figur 45. Jalur Sirkulasi 5

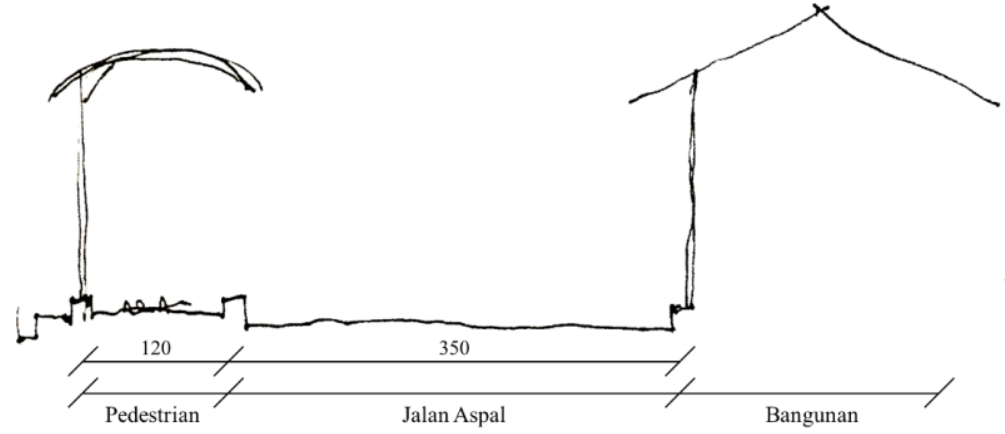

Figur 46. Potongan Jalur Sirkulasi 5

\section{Jalur Sirkulasi 6}

Jalur ini terletak di depan asrama anis dan muray. Dengan lebar sebesar 1.2 meter, material keramik 30 x $30 \mathrm{~cm}$ yang dilengkapi dengan ubin pemandu di bagian tengahnya, serta dinaungi oleh naungan sederhana berbahan atap fiber warna biru setinggi 2.5 meter. Sisi yang berbatasan dengan jalan aspal dihubungkan dengan Ramp yang menurun. Perbedaan ketinggiannya adalah 10 $\mathrm{cm}$. Pembatas jalan aspal selain Ramp dengan jalur pedestrian adalah tanaman perdu setinggi 60 $\mathrm{cm}$.

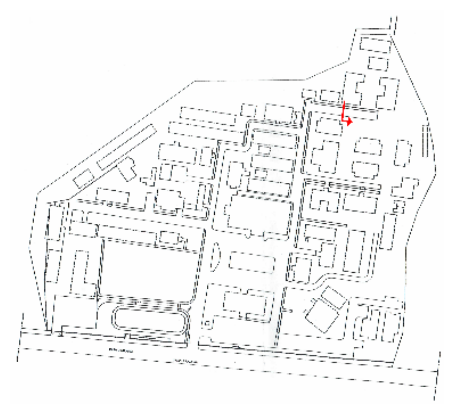

Figur 47. Letak Jalur Sirkulasi 6 di Rencana Tapak PSBN Wyata Guna

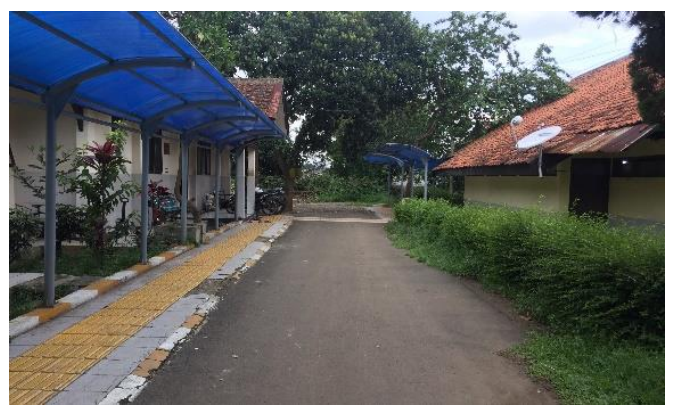

Figur 48. Jalur Sirkulasi 6 


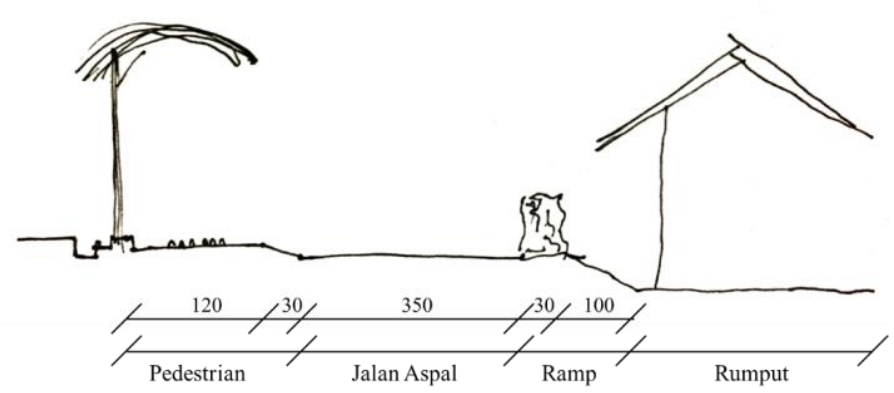

Figur 49. Potongan Jalur Sirkulasi 6

\section{Jalur Sirkulasi 7}

Jalur ini berada di dekat area asrama anak-anak dan asrama perempuan. Berada di sisi Timur PSBN Wyata Guna. Jalur sirkulasi ini seperti jalur lainnya menggunakan keramik 30 x 30 $\mathrm{cm}$ sebagai material penutup lantainya serta dilengkapi ubin pemandu di bagian tengahnya dan hand railling setinggi 1 meter di salah satu sisinya. Di sisi lainnya yang berbatasan dengan rumput terdapat curb setinggi $10 \mathrm{~cm}$. Jalur ini ternaungi oleh naungan sederhana setinggi 2.5 meter yang bertumpu pada tiang-tiang sederhana dari besi. Material penutup atapnya adalah fiber berwarna biru.

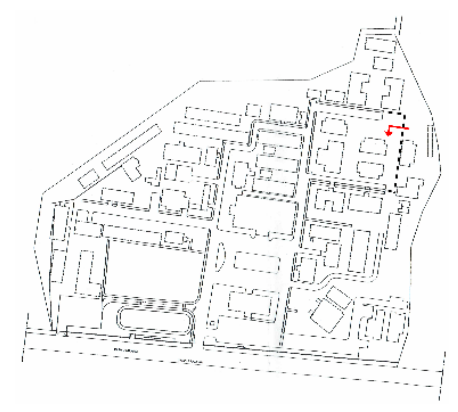

Figur 50. Letak Jalur Sirkulasi 7 di Rencana Tapak PSBN Wyata Guna

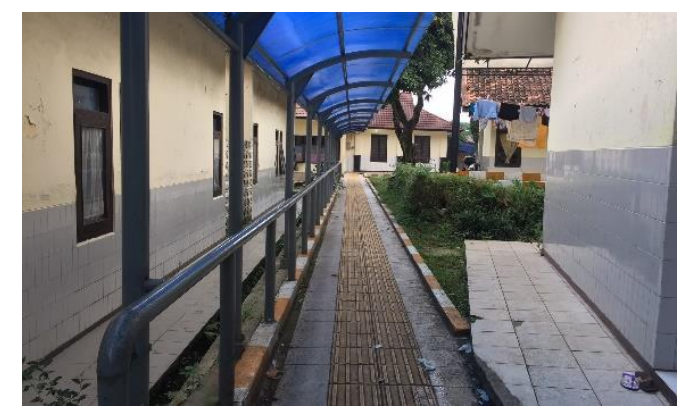

Figur 51. Jalur Sirkulasi 7

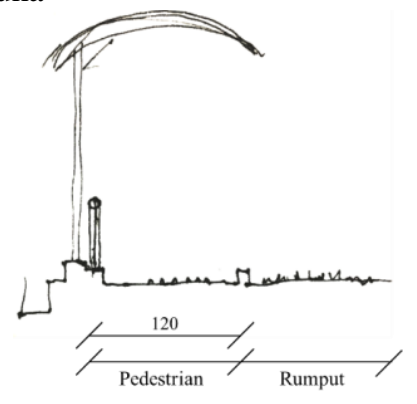

Figur 52. Potongan Jalur Sirkulasi 7

\section{Jalur Sirkulasi 8}

Jalur ini berada di antara asrama cempaka dan dapur umum. Tidak dilengkapi dengan naungan seperti pada jalur sirkulasi yang lainnya. Material penutup lantai jalur ini adalah keramik $30 \times 30 \mathrm{~cm}$ yang dilengkapi dengan ubin pemandu di bagian tengah-tengahnya. Lebar jalur ini adalah 1.2 meter dibatasi oleh bidang yang dinaikkan setinggi $10 \mathrm{~cm}$ pada kedua sisinya. Di sisi 
kanan dan kiri dari jalur pedestrian adalah bidang rumput sebagai penghijauan dan penyerap air hujan.

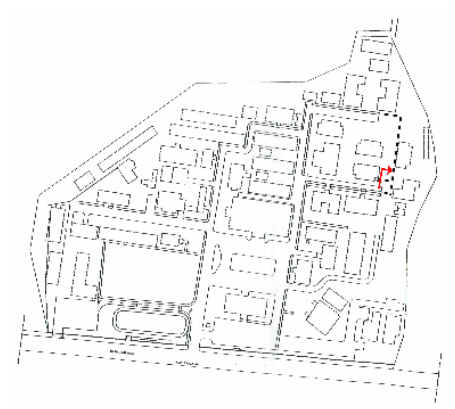

Figur 53. Letak Jalur Sirkulasi 8 di Rencana Tapak PSBN Wyata Guna

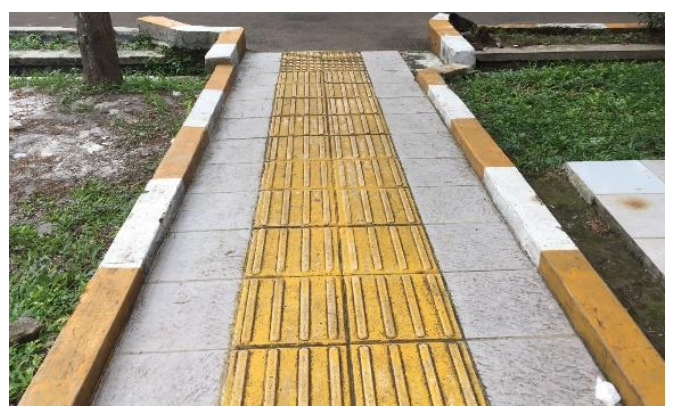

Figur 54. Jalur Sirkulasi 8

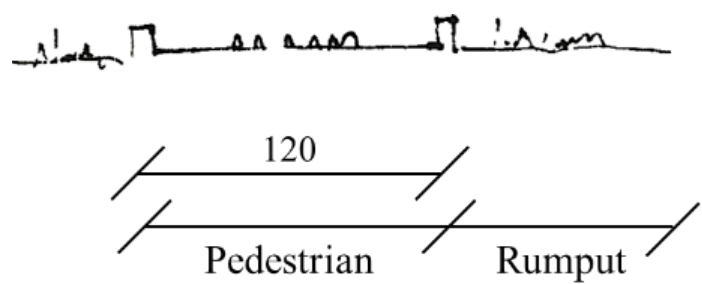

Figur 55. Potongan Jalur Sirkulasi 8

\section{Jalur Sirkulasi 9}

Jalur ini berada tepat di samping bangunan dapur umum PSBN Wyata Guna. Dengan lebar jalan sebesar 1 meter, jalur ini dibatasi oleh dinding dapur yang dilapis keramik setinggi 1.2 meter dan perbedaan elevasi yang diturunkan setinggi $20 \mathrm{~cm}$ dari jalan aspal. Jalan aspal pada jalur ini selebar 3.5 meter sebagai jalur bagi kendaraan bermotor namun jalan aspal ini buntu dengan dapur umum sebagai bangunan akhirnya. Selain jalur pedestrian, sisi lain jalan aspal dibatasi oleh curb setinggi $20 \mathrm{~cm}$. Kemudian dilanjutkan dengan bidang rumput dan saluran drainase selebar $30 \mathrm{~cm}$.

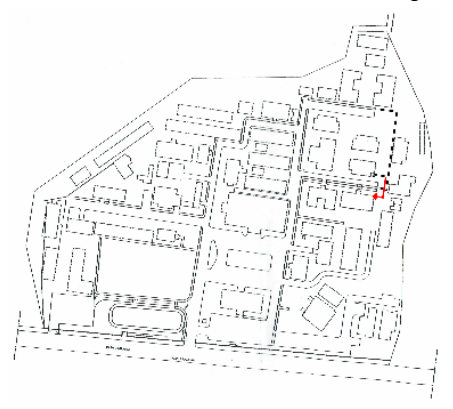

Figur 56. Letak Jalur Sirkulasi 9 di Rencana Tapak PSBN Wyata Guna

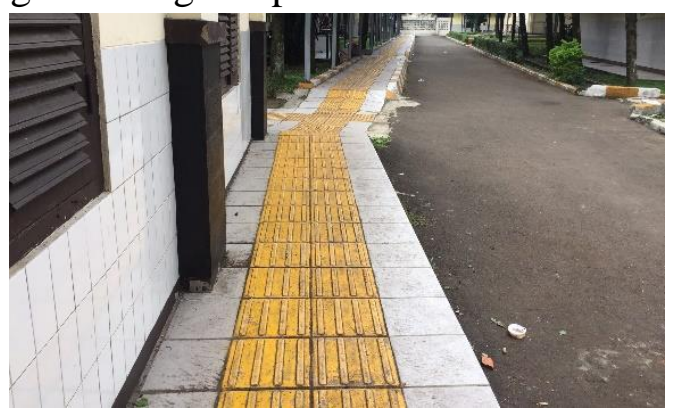

Figur 57. Jalur Sirkulasi 9 


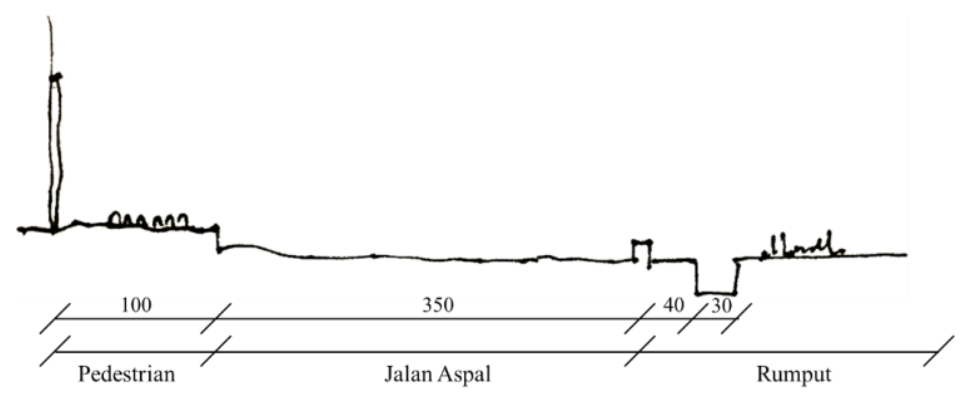

Figur 58. Potongan Jalur Sirkulasi 9

\section{Jalur Sirkulasi 10}

Jalur ini adalah jalur tersier PSBN Wyata Guna. Berada di antara dua bangunan asrama, menjadi jalan pintas yang digunakan oleh penyandang tunanetra. Karenanya jalur ini tidak dilengkapi dengan ubin pemandu. Material penutup lantainya adalah keramik 30 x $30 \mathrm{~cm}$. Lebar jalur sirkulasi ini hanya $60 \mathrm{~cm}$ dan berbatasan langsung dengan saluran drainase terbuka selebar $30 \mathrm{~cm}$ dengan kedalaman $40 \mathrm{~cm}$ di salah satu sisinya. Sedangkan di sisi lainnya, jalur ini dibatasi oleh dinding asrama yang dilapis keramik setinggi 1.2 meter.

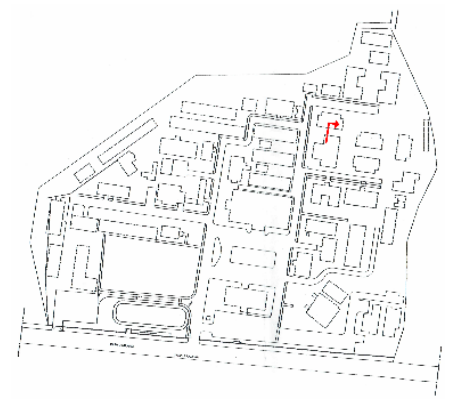

Figur 59. Letak Jalur Sirkulasi 10 di Rencana Tapak PSBN Wyata Guna

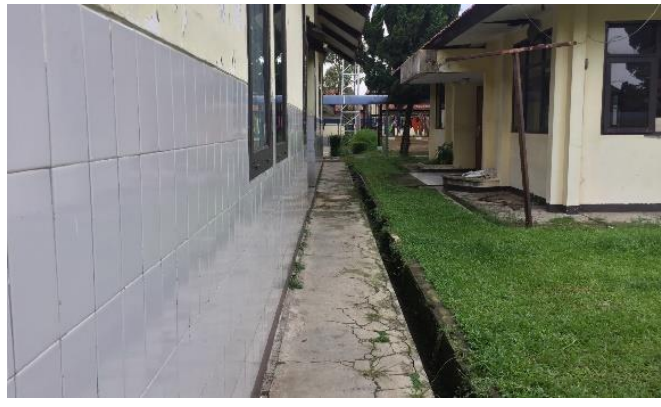

Figur 60. Jalur Sirkulasi 10

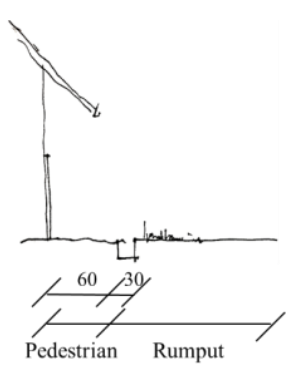

Figur 61. Potongan Jalur Sirkulasi 10

Elemen fisik pembentuk jalur sirkulasi PSBN Wyata Guna yang berperan dalam orientasi dan mobilitas penyandang tunanetra dapat dijabarkan ke dalam beberapa kelompok. Kelompok ini disusun berdasarkan elemen fisik yang mendefinisikan ruang menurut D. K. Ching dalam bukunya bukunya Arsitektur: Bentuk, Ruang, dan Susunannya, yaitu sebagai berikut:

Tabel 1. Elemen Fisik Pembentuk Jalur Sirkulasi PSBN Wyata Guna 


\begin{tabular}{|l|l|l|}
\hline \multicolumn{2}{|c|}{ TEORI } & \multicolumn{1}{c|}{ OBSERVASI } \\
\hline Bidang Horizontal & Bidang Dasar & $\begin{array}{l}\text { Ubin Pemandu } \\
\text { Beda Material }\end{array}$ \\
\cline { 2 - 3 } & Bidang Dasar yang Dinaikkan & $\begin{array}{l}\text { Ramp } \text { (tanjakan) } \\
\text { Undakan }\end{array}$ \\
\cline { 2 - 3 } & Bidang Dasar yang Diturunkan & Ramp (turunan) \\
\hline Bidang Vertikal & Bidang Vertikal Linier & Tiang Koridor \\
\cline { 2 - 3 } & Bidang Vertikal Tunggal & $\begin{array}{l}\text { Dinding Keramik } \\
\text { Tanaman Perdu }\end{array}$ \\
\cline { 2 - 3 } & Bidang-Bidang Sejajar & Dinding antar Bangunan \\
\hline
\end{tabular}

\section{2 ELEMEN FISIK PEMBENTUK LINGKUNGAN FISIK YANG BERPERAN DALAM ORIENTASI DAN MOBILITAS TUNANETRA DI PSBN WYATA GUNA UBIN PEMANDU}

Ubin pemandu berada di hampir seluruh jalur sirkulasi pedestrian di lingkungan PSBN Wyata Guna sejak 2014. Ubin pemandu sangat memudahkan orientasi dan mobilitas penyandang tunanetra. Terdiri dari dua jenis, garis lurus panjang untuk berjalan terus dan bulat-bulat untuk persimpangan. Dengan adanya ubin pemandu, penyandang tunanetra dapat berjalan tetap di jalur yang aman.
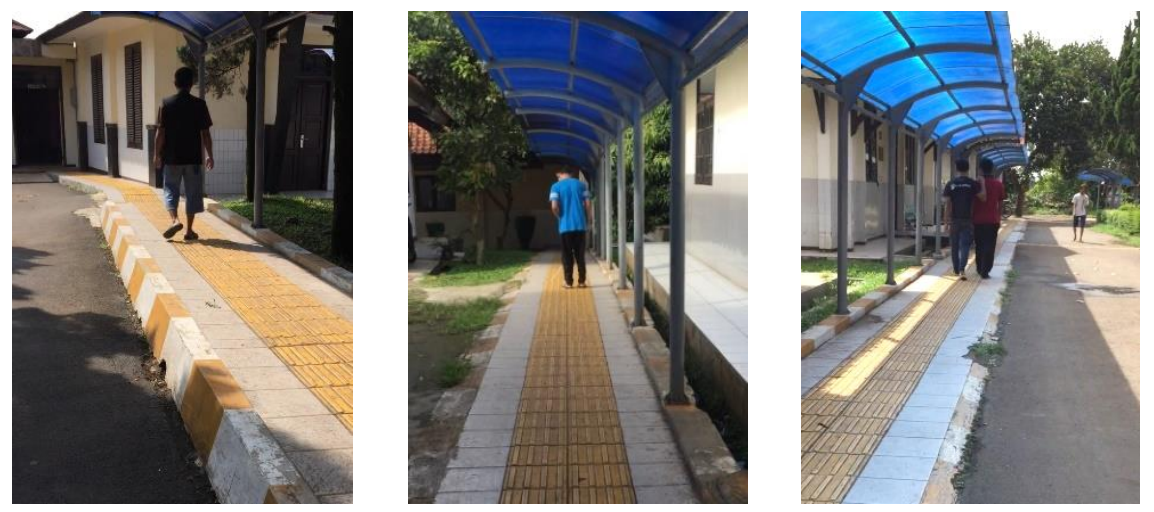

Figur 62. Ubin Pemandu dimanfaatkan ketika Orientasi dan Mobilitas

Namun pada penerapannya di lingkungan fisik PSBN Wyata Guna, seringkali ditemukan pola pemasangan ubin pemandu yang tidak sesuai dengan ketentuan standar yang berlaku, diantaranya adalah pemasangan ubin pemandu yang tidak menerus sehingga hal ini dapat membingungkan proses orientasi dan mobilitas penyandang tunanetra. Mereka akan merasa kehilangan arah dan tersesat. Selain itu ditemukan juga pemasangan ubin pemandu yang tidak menerus dengan ujung menuju saluran drainase terbuka. Hal ini dapat membahayakan penyandang tunanetra, tidak jarang mereka terperosok ke dalam saluran drainase. Ada juga pemasangan yang keliru pada ubin pemandu garis lurus panjang ketika bertemu dengan ubin pemandu bulat-bulat. Hal ini dapat menyebabkan adanya informasi yang terabaikan dan tidak lengkap yang diterima oleh penyandang tunanetra. 


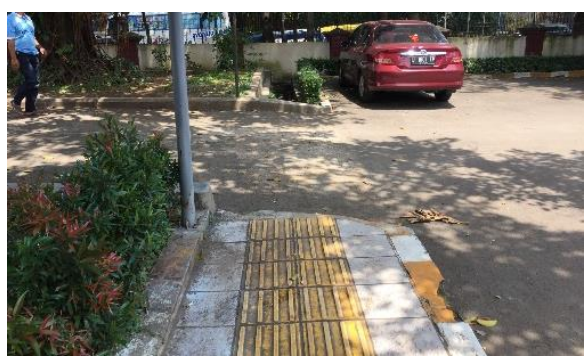

Figur 63. Pemasangan Ubin Pemandu yang Tidak Menerus

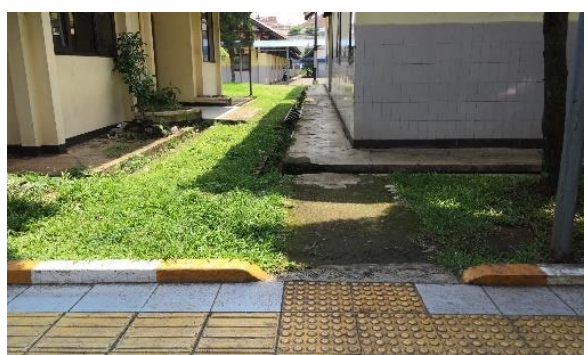

Figur 65. Ubin Pemandu yang Tidak Menerus dan Berujung ke Saluran Drainase Terbuka

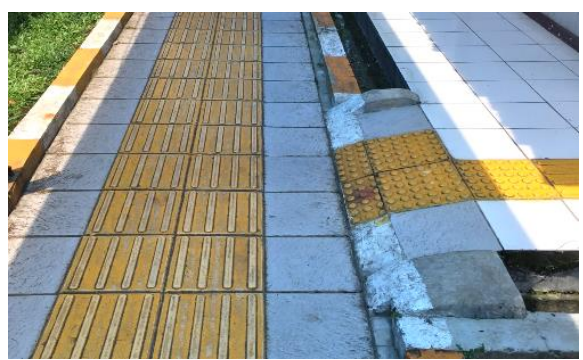

Figur 64. Ubin Pemandu Bulat-Bulat yang Tidak Terhubung dengan Ubin Pemandu di Jalur Utama

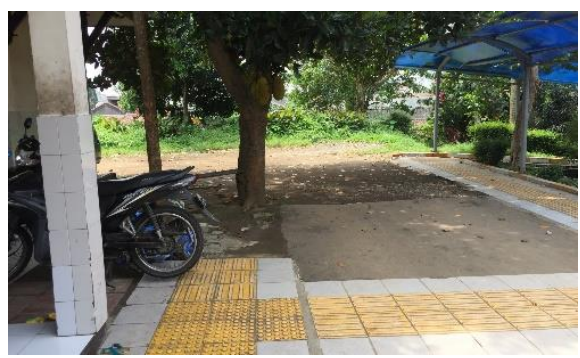

Figur 66. Ubin Pemandu yang Tidak Menerus dan Berujung ke Pohon Nangka

\section{Beda Material}

Beda material sering digunakan sebagai ciri untuk penyandang tunanetra berorientasi dan mobilitas di lingkungan PSBN Wyata Guna. Perbedaan yang sering ditemui umumnya adalah antara material aspal dengan ubin keramik, material ubin keramik dengan rumput, material jalan beton dengan rumput. Dengan adanya perbedaan material, penyandang tunanetra dapat mengetahui batas jalur aman untuk pedestrian agar mereka tidak berjalan ke tengah jalur yang berbahaya.

\section{Ramp (Tanjakan)}

Ramp (Tanjakan) berada di hampir seluruh kawasan PSBN Wyata Guna, karena konturnya yang meninggi dari sisi selatan ke utara. Sisi utara yang ditempati asrama-asrama penyandang tunanetra menjadi

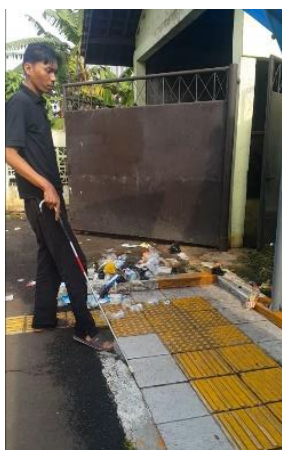

Figur 67. Beda Material dimanfaatkan ketika Orientasi dan Mobilitas bagian yang lebih tinggi dari bangunan publik lainnya. Sehingga untuk mencapai asrama, penyandang tunanetra pasti melewati jalan menanjak. Pada belokan jalan juga, umumnya ada Ramp yang menanjak sehingga tanjakan dapat menjadi salah satu elemen fisik yang menandai belokan. 

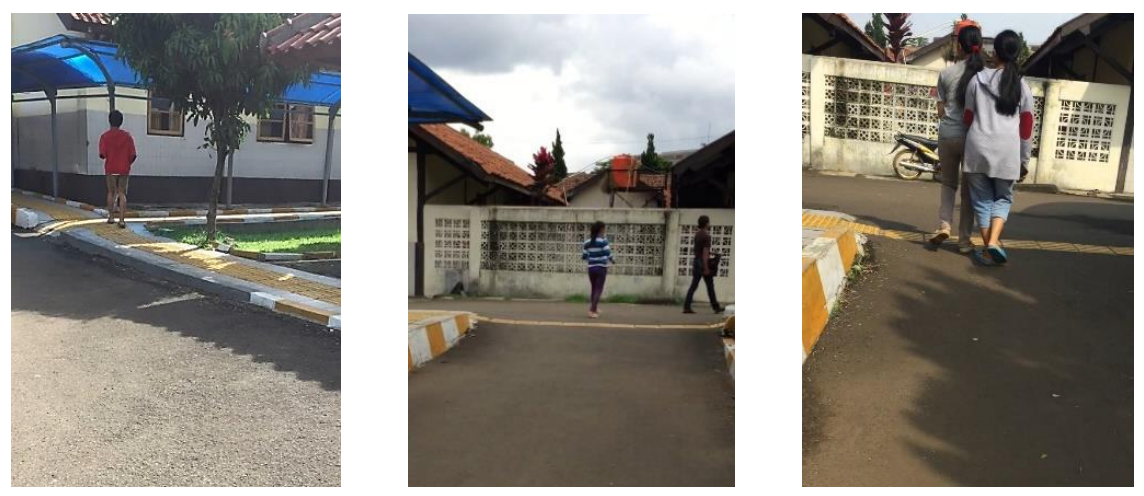

Figur 68. Ramp (Tanjakan) dimanfaatkan ketika Orientasi dan Mobilitas

\section{Undakan}

Undakan yang dimaksud adalah perbedaan elevasi, seperti kanstin, anak tangga, dll. Di lingkungan fisik manapun, tidak hanya di PSBN Wyata Guna, umumnya pasti terdapat perbedaan elevasi sebagai pembatas jalur-jalur yang ada. Undakan terutama anak tangga dapat ditemui sebagai salah satu ciri tipikal pintu masuk bangunan di PSBN Wyata Guna. Umumnya ada kenaikkan dua hingga tiga anak tangga untuk mencapai pintu masuk bangunan yang dituju.
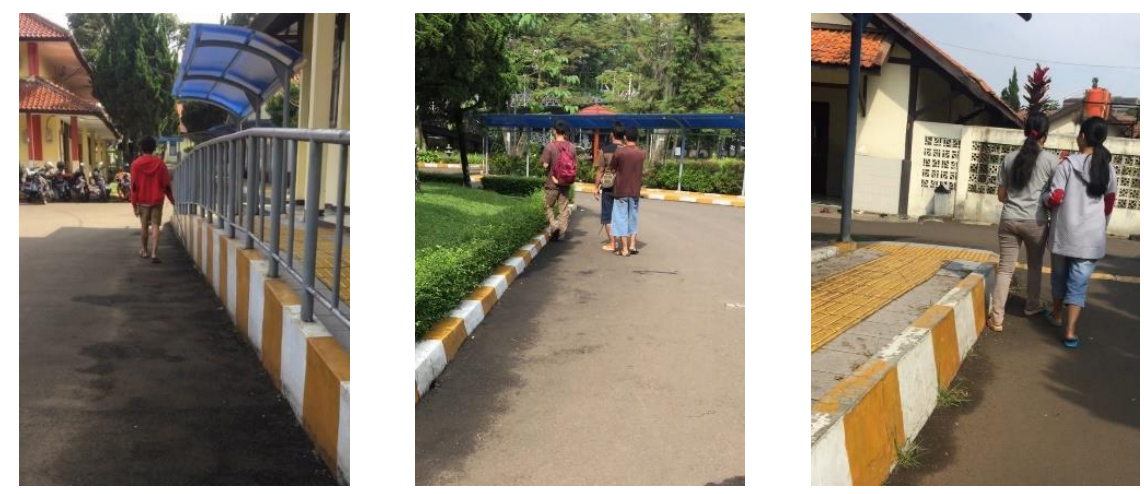

Figur 69. Undakan dimanfaatkan ketika Orientasi dan Mobilitas

\section{Ramp (Turunan)}

Mirip dengan Ramp (tanjakan), Ramp (turunan) juga berada di hampir seluruh kawasan PSBN Wyata Guna, karena kontur kawasan ini. Sisi selatan yang ditempati bangunan publik menjadi bagian yang lebih rendah dari asrama-asrama penyandang tunanetra lainnya. Sehingga untuk mencapai kelas, kantor, dll. penyandang tunanetra pasti melewati jalan menurun. Pada belokan jalan juga, umumnya ada Ramp sehingga turunan dapat menjadi salah satu elemen fisik yang menandai belokan. 

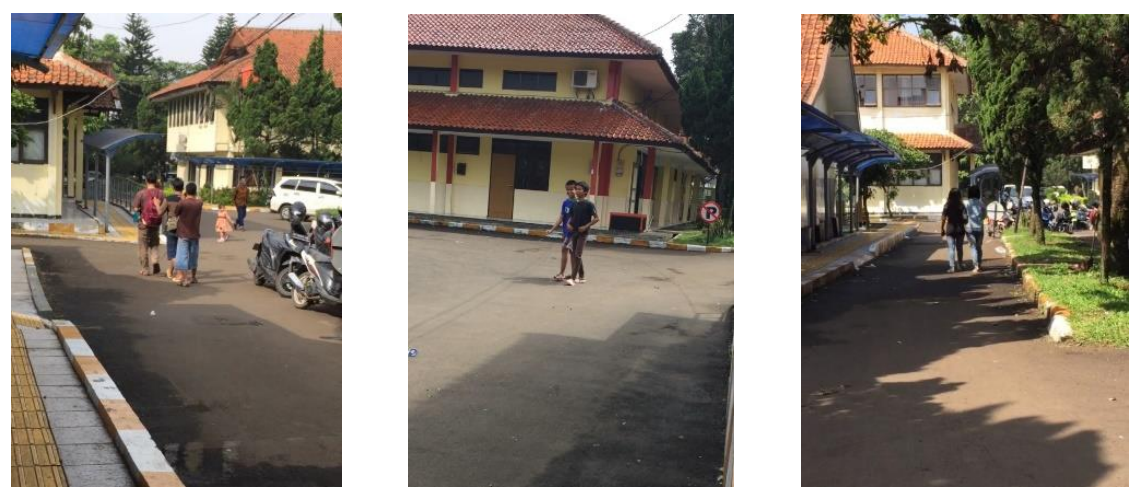

Figur 70. Ramp (Turunan) dimanfaatkan ketika Orientasi dan Mobilitas

\section{Tiang Koridor}

Tiang ini merupakan kolom penyangga dari naungan jalur sirkulasi pedestrian setinggi 2.5 meter. Berbahan dasar dari besi hollow bulat yang dicat abu. Karena bahannya besi, maka ketika terpukul tongkat penyandang tunanetra, akan mengeluarkan bunyi yang cukup nyaring. Dari bunyi yang ditimbulkan tersebut, penyandang tunanetra dapat menyusuri jalur pedestrian dengan mengikuti keberadaan dari tiang-tiang ini sehingga mereka tetap berjalan tetap pada jalur yang aman.

\section{Dinding Keramik}

Dinding di lingkungan PSBN Wyata Guna dicat putih agak kekuningan dan dilapis keramik setinggi 1.2 meter dari bidang dasarnya.

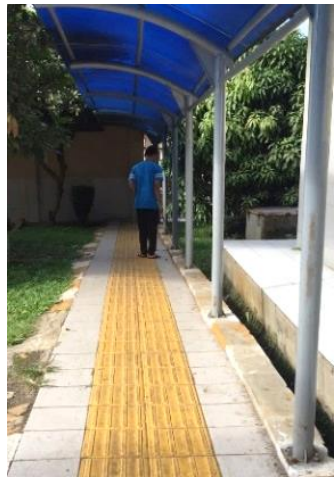

Figur 71. Tiang Koridor dimanfaatkan ketika Orientasi dan Mobilitas Keramik modular ini memberikan tekstur ketika disentuh oleh penyandang tunanetra, sehingga memudahkan mereka untuk menyusuri dinding. Dengan menyusuri dinding, penyandang tunanetra dapat mengetahui bila jalan lurus atau telah sampai di ujung bangunan (mentok) dan harus berbelok.
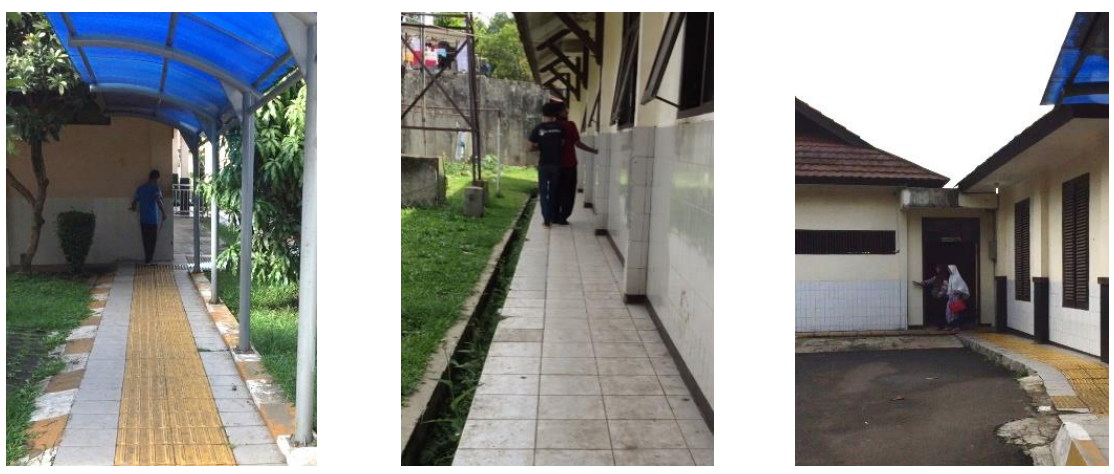

Figur 72. Dinding Keramik dimanfaatkan ketika Orientasi dan Mobilitas

\section{Tanaman Perdu}


Tanaman perdu cukup jarang ditemui sebagai pembatas jalur sirkulasi pedestrian di lingkungan PSBN Wyata Guna. Namun keberadaannya seringkali turut membantu penyandang tunanetra dalam melakukan orientasi dan mobilitas. Terdapat beberapa macam tanaman perdu yang dibedakan dari ketinggiannya, ada yang setinggi paha orang dewasa, ada yang setinggi dada orang dewasa, sehingga tanaman perdu dapat diraba dan disusuri supaya penyandang tunanetra berjalan tetap di sisi jalan dan pada jalur yang aman.

\section{Hand Railling}

Hand Railling dapat ditemui sebagai pembatas jalur sirkulasi pedestrian di lingkungan PSBN Wyata Guna dekat asrama Cempaka. Hand Railling terbuat dari bahan besi hollow bulat yang dicat abu, sama seperti tiang koridor penyangga naungan. Hand Railling dibuat setinggi 1 meter agar ideal untuk tinggi orang dewasa sebagai pegangan dan untuk pembatas anak kecil agar tidak terpeleset ke drainase di sisi jalur sirkulasi.

\subsection{PERANAN LINGKUNGAN FISIK TERHADAP ORIENTASI DAN MOBILITAS PENYANDANG TUNANETRA}

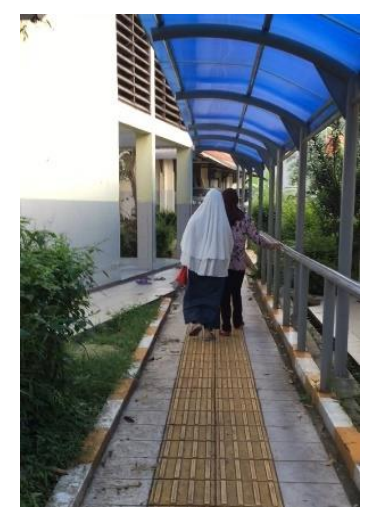

Figur 73. Hand Railling dimanfaatkan ketika Orientasi dan Mobilitas

Peranan lingkungan fisik terhadap orientasi dan mobilitas penyandang tunanetra diperoleh melalui wawancara rekaman perilaku mereka. Dari hasil rekaman perilaku responden dapat diketahui bahwa: (1) Penyandang tunanetra yang menggunakan ubin pemandu untuk orientasi dan mobilitas di lingkungan fisik PSBN Wyata Guna sebanyak 71.43\% (2) Penyandang tunanetra yang mengandalkan perbedaan material untuk orientasi dan mobilitas di lingkungan fisik PSBN Wyata Guna sebanyak 28.5\% (3) Penyandang tunanetra menjadikan Ramp (tanjakan) sebagai acuan untuk orientasi dan mobilitas di lingkungan fisik PSBN Wyata Guna sebanyak 50\% (4) Penyandang tunanetra yang menggunakan undakan untuk orientasi dan mobilitas di lingkungan fisik PSBN Wyata Guna sebanyak 50\% (5) Penyandang tunanetra yang mengandalkan Ramp (turunan) untuk orientasi dan mobilitas di lingkungan fisik PSBN Wyata Guna sebanyak 71.43\% (6) Penyandang tunanetra menjadikan tiang koridor sebagai acuan untuk orientasi dan mobilitas di lingkungan fisik PSBN Wyata Guna sebanyak 7.14\% (7) Penyandang tunanetra yang menggunakan dinding keramik untuk orientasi dan mobilitas di lingkungan fisik PSBN Wyata Guna sebanyak 57.1\% (8) Penyandang tunanetra yang mengandalkan tanaman perdu untuk orientasi dan mobilitas di lingkungan fisik PSBN Wyata Guna sebanyak 0\% (9) Penyandang tunanetra yang menjadikan hand railling sebagai acuan untuk orientasi dan mobilitas di lingkungan fisik PSBN Wyata Guna sebanyak $7.14 \%$

\section{KESIMPULAN}

Perilaku penyandang tunanetra ketika orientasi dan mobilitas sangatlah dipengaruhi lingkungan fisik sekitarnya tapi selain itu, juga dipengaruhi kemampuan persepsi masing-masing individu. Semakin baik persepsi individu terhadap lingkungan fisiknya ketika dia melakukan orientasi dan mobilitas, maka semakin sedikit elemen fisik yang dia gunakan.

Elemen pembentuk lingkungan fisik di PSBN Wyata Guna terbagi dalam dua kelompok besar yaitu bidang horizontal dan bidang vertikal. Sedikitnya dari dua kelompok tersebut ada sembilan varian elemen fisik yang memberikan konsep informasi kepada penyandang tunanetra 
dalam melakukan orientasi dan mobilitas, di antaranya adalah ubin pemandu, beda material, Ramp (tanjakan), undakan, Ramp (turunan), tiang koridor, dinding keramik, tanaman perdu, dan hand railling.

Kesimpulan penelitian ini adalah bahwa lingkungan fisik yang berperan dalam orientasi dan mobilitas penyandang tunanetra adalah bangunan (saat orientasi) dan jalur sirkulasi (saat mobilitas). Di lingkungan PSBN Wyata Guna terdapat beberapa bangunan yang berfungsi sebagai markah tanah. Bangunan ini memiliki ciri-ciri khusus, yang membedakan satu bangunan dengan bangunan yang lainnya, terutama di bagian pintu masuknya seperti anak tangga sejumlah tertentu, tanjakan menurun atau menanjak. Hal ini memudahkan penyandang tunanetra untuk mengenalinya sebagai titik orientasi saat melakukan mobilitas di lingkungan PSBN Wyata Guna. Sedangkan untuk peranan lingkungan fisik saat penyandang tunanetra melakukan mobilitas, terlihat dari elemen fisik pembentuk jalur sirkulasi yang paling sering digunakan secara efektif, yaitu ubin pemandu dan Ramp (turunan). Karena sepuluh dari empat belas responden menggunakan ubin pemandu dan Ramp (turunan) sebagai elemen fisik pemberi informasi ketika mereka melakukan orientasi dan mobilitas di lingkungan PSBN Wyata Guna. Sedangkan elemen fisik yang paling jarang digunakan dan keberadaannya kurang efektif adalah tanaman perdu. Dari empat belas responden yang diamati, tidak satupun yang menggunakan tanaman perdu sebagai elemen fisik yang memberikan informasi orientasi dan mobilitas untuk mereka. Hal ini dikarenakan tidak semua jalur sirkulasi dilengkapi tanaman perdu sebagai batas jalurnya. Selain itu, letaknya yang di pinggir jalur sirkulasi juga menyebabkan tanaman perdu tidak tersentuh oleh penyandang tunanetra yang terbiasa berjalan di tengah-tengah jalur agar tidak jatuh ke saluran drainase samping jalur.

\section{DAFTAR PUSTAKA}

Bernardo, Jose. (1970). Architecture for blind persons. New outlook for the blind, 64 (8), 262-265.

Ching, F. D. K. 1991. Arsitektur: Bentuk, Ruang dan Susunannya.Terjemahan Paulus Hanoto Adjie. Jakarta: Airlangga.

Rahardja, Djadja. "Konsep Dasar Orientasi dan Mobilitas". http://djrahardja.blogspot.co.id/2008/04/konsep-dasar-orientasi-dan-mobilitas.html (diakses pada tanggal 8 Maret 2017 21.41)

Rudiyati, Sari. Orientasi Mobilitas Penyandang Tunanetra. Diakses pada tanggal 27 Januari 2017 dari http://staff.uny.ac.id/sites/default/files/pendidikan/Dr.\%20Sari\%20Rudiyati,\%20M.Pd./Materi\%2 0Orientasi\%20dan\%20Mobilitas.pdf

PSBN Wyata Guna. 2005. Modul Pembimbingan Orientasi Mobilitas Tahapan Observasi, Rehabilitasi, dan Resosialisasi. Bandung: Departemen Sosial Republik Indonesia, Direktorat Jenderal Pelayanan dan Rehabilitasi Sosial. 